\title{
Early Phacoemulsification After Acute Angle Closure in Patients With Coexisting Cataract
}

Citation for published version (APA):

Romkens, H. C. S., Beckers, H. J. M., Schouten, J. S. A. G., Nuijts, R. M. M. A., Berendschot, T. T. J. M., Breusegem, C. M., \& Webers, C. A. B. (2019). Early Phacoemulsification After Acute Angle Closure in Patients With Coexisting Cataract. Journal of Glaucoma, 28(2), E34-E35.

https://doi.org/10.1097/IJG.0000000000001111

Document status and date:

Published: 01/02/2019

DOI:

10.1097/IJG.0000000000001111

Document Version:

Publisher's PDF, also known as Version of record

Document license:

Taverne

Please check the document version of this publication:

- A submitted manuscript is the version of the article upon submission and before peer-review. There can be important differences between the submitted version and the official published version of record.

People interested in the research are advised to contact the author for the final version of the publication, or visit the DOI to the publisher's website.

- The final author version and the galley proof are versions of the publication after peer review.

- The final published version features the final layout of the paper including the volume, issue and page numbers.

Link to publication

\footnotetext{
General rights rights.

- You may freely distribute the URL identifying the publication in the public portal. please follow below link for the End User Agreement:

www.umlib.nl/taverne-license

Take down policy

If you believe that this document breaches copyright please contact us at:

repository@maastrichtuniversity.nl

providing details and we will investigate your claim.
}

Copyright and moral rights for the publications made accessible in the public portal are retained by the authors and/or other copyright owners and it is a condition of accessing publications that users recognise and abide by the legal requirements associated with these

- Users may download and print one copy of any publication from the public portal for the purpose of private study or research.

- You may not further distribute the material or use it for any profit-making activity or commercial gain

If the publication is distributed under the terms of Article $25 \mathrm{fa}$ of the Dutch Copyright Act, indicated by the "Taverne" license above, 
Letter to the Editor: Early Phacoemulsification After Acute Angle Closure in Patients With Coexisting Cataract

\section{To the Editor:}

I would like to mention a few points in relation to the article by Romkens et $\mathrm{al}^{1}$ on "Early Phacoemulsification After Acute Angle Closure in Patients With Coexisting Cataract."

The patients in this study underwent phacoemulsification within 3 months (range, 1 to 84 days) after an attack of acute primary angle closure (APAC). What I have observed is that, depending on the time of patient presentation after APAC, for a majority of patients, it generally takes around 2 to 3 days for epithelial oedema to subside and a weeks' time for the corneal stroma to clear reasonably and inflammation to resolve, with medical management. Hence, it is unclear as to, how the surgery was performed on the first day after an acute attack of APAC, as corneal oedema precludes sufficient visibility to perform cataract surgery.

The preoperative and postoperative gonioscopy findings and duration of follow-up after the cataract surgery are not mentioned. The importance of performing gonioscopy, once the cornea clears, is to know the extent of peripheral anterior synechiae, which can cause trabecular dysfunction and an increase in intraocular pressure during the followup period.

As the preoperative and postoperative optic disc and visual field information is not known from the study, how did the authors divide the subgroups into PAC and PAC glaucoma. The optic disc, visual field, ${ }^{2}$ and retinal nerve fiber layer thickness ${ }^{3}$ show changes after APAC and if the patient has progressed to PAC glaucoma, combining phacoemulsification with trabeculectomy would have been more beneficial for the patient in terms of

\footnotetext{
Disclosure: The authors declare no conflict of interest.

DOI: 10.1097/IJG.0000000000001110
}

the intraocular pressure reduction and reducing the number of glaucoma medications.

Tarannum Mansoori, MS Sita Lakshmi Glaucoma Center, Anand Eye Institute, Nagendra Nagar, Habsiguda Hyderabad, Telangana, India

\section{REFERENCES}

1. Römkens HCS, Beckers HJM, Schouten JSAG, et al. Early phacoemulsification after acute angle closure in patients with coexisting cataract. J Glaucoma. 2018;27: 711-716.

2. Sng CC, See JS, Ngo CS, et al. Changes in retinal nerve fibre layer, optic nerve head morphology, and visual field after acute primary angle closure. Eye (Lond). 2011;25:619-625.

3. Mansoori T, Viswanath K, Balakrishna N. Quantification of retinal nerve fiber layer thickness after unilateral acute primary angle closure in Asian Indian eyes. J Glaucoma. 2013;22:26-30.

\section{Early Phacoemulsification After Acute Angle Closure in Patients With Coexisting Cataract}

\section{In Reply:}

We thank Mansoori for his comments on our manuscript titled "Early phacoemulsification after acute angle closure in patients with coexisting cataract," 1 and we feel pleased to have the opportunity to respond.

Cataract surgery was solely performed after the acute angle-closure (AAC) attack was treated according to

Disclosure: H.J.M.B. reports grants and personal fees from Alcon, Santen, Allergan; personal fees from MSD, outside the submitted work. J.S.A.G.S. reports grants and personal fees from Novartis, Sanofi, outside the submitted work. R.M.M.A.N. reports grants and personal fees from Alcon; grants from Bausch \& Lomb, Gebauer, HumanOptics, Ophthec, Acufocus; personal fees from Asico, TheaPharma, outside the submitted work. C.A.B.W. reports grants and personal fees from Alcon; personal fees from Allergan, MSD, Pfizer, outside the submitted work. The remaining authors declare no conflict of interest.

DOI: 10.1097/IJG.0000000000001111 our standard protocol with topical and systemic medical therapy to lower intraocular pressure (IOP) and clear corneal edema, after which laser peripheral iridotomy was performed as soon as the cornea permitted good visualization. In the 1 case in which cataract surgery was performed after 1 day, the AAC attack resolved quickly, and the cataract surgery could be performed because of sufficient visualization of the cornea.

The gonioscopy performed during the AAC attack reported that the trabecular meshwork was not visible and that the anterior chamber angle was closed. As a retrospective study, we acknowledged that it had some potential limitations and that further studies should confirm our findings. As mentioned, this resulted in missing data on the gonioscopy findings after cataract surgery. However, this study was solely performed to evaluate the effect on IOP number of glaucoma medications, visual acuity, and complications of cataract extraction after an AAC attack, and the extended study on gonioscopy findings fell outside the scope of this study. Nevertheless, one could hypothesize that the IOP decrease after surgery could only have taken place if the anterior chamber angle was opened, and there were little to no synechiae.

Primary angle closure (PAC) (glaucoma) was defined according to the definition of the consensus reading. ${ }^{2}$ PAC was defined as angle closure in three or more quadrants with either raised IOP and/or peripheral anterior synechiae, without glaucomatous visual field defects and without glaucomatous optic neuropathy. Primary angle closure glaucoma was defined as PAC but with reproducible visual field defects, glaucomatous optic neuropathy, or both.

The primary goal of this study was to report data on cataract extraction alone within 3 months after the AAC attack. There was no further follow-up concerning progression from PAC to primary angle closure glaucoma. Visual fields are performed several months postoperatively after which is determined whether further additional surgery is necessary. This study showed that early phacoemulsification with intraocular lens implantation results in a reduction in IOP and number of glaucoma medications after an AAC glaucoma crisis in patients with coexisting cataract. It was not designed to evaluate the effect of a combined 
phacotrabeculectomy, rather it could be stated that early phacoemulsification is meaningful, and a trabeculectomy could be performed in a second surgery.

\author{
Hellen C.S. Römkens, MD* \\ Henny J.M. Beckers, MD, PhD* \\ Jan S.A.G. Schouten, MD, PhD $†$ \\ Rudy M.M.A. Nuijts, MD, PhD* \\ Tos T.J.M. Berendschot, PhD* \\ Christophe M. Breusegem, MD* \\ Carroll A.B. Webers, MD, PhD* \\ * Maastricht University Medical Center \\ University Eye Clinic Maastricht \\ Maastricht, The Netherlands \\ $\dagger$ Canisius Wilhelmina Hospital, Nijmegen
}

\section{REFERENCES}

1. Romkens HCS, Beckers HJM, Schouten J, et al. Early phacoemulsification after acute angle closure in patients with coexisting cataract. J Glaucoma. 2018;27:711-716.

2. Weinreb RN. Angle Closure and Angle Closure Glaucoma. The Hague, The Netherlands: Kugler Publications; 2006.

\section{e-Letter-to the Editor to: Park J.-H. et al "Peripapillary Vessel Density in} Glaucomatous Eyes: Comparison Between Pseudoexfoliation Glaucoma and Primary Open-angle Glaucoma"

\section{To the Editor:}

I read with interest the recently published online first article "Peripapillary vessel density in glaucomatous eyes: comparison between pseudoexfoliation glaucoma and primary open-angle glaucoma" by Park et al. ${ }^{1}$ In this article, the authors measured peripapillary vessel density using optical coherence tomography angiography on 39 exfoliative glaucoma eyes and 39 primary open-angle glaucoma eyes which,

\footnotetext{
Disclosure: The author declares no conflict of interest.
}

DOI: 10.1097/IJG.0000000000001112 according to the authors' statement, were matched. Using the unpaired $t$ test they found similar peripapillary retinal nerve fiber layer thickness (RNFLT) and $\sim 2 \%$ lower peripapillary vessel density in the exfoliative glaucoma group $(24.21 \% \pm 5.20 \%$ vs. $26.38 \% \pm 4.28 \%$; $P=0.048)$. The authors extensively discuss the published data, which suggest that perfusion is reduced or damaged in exfoliation, and interpret their findings as new data that support the information on vascular alterations in exfoliation. However, based on their presented data, this interpretation remains unproven, as the methodical details of the study do not allow drawing any conclusion on the between-group differences.

First, the authors enrolled eyes that underwent uncomplicated cataract surgery. It is known that removing cataract increases the strength of the reflected light, which causes improved image quality and higher measured signal, compared with the precataract surgery values. ${ }^{2}$ In addition, exfoliative syndrome and glaucoma are strongly associated with clinically significant nuclear cataract, which considerably decreases image quality. ${ }^{3,4}$ The authors do not provide any information on the number and distribution of pseudophakic eyes in the 2 groups; they do not report on cataract density; and they do not report on the image quality scores. Thus, it is possible that the minimally lower peripapillary vessel density values measured in the exfoliative glaucoma group in 3 locations are caused by the influence of greater lens opacity and the lower number of pseudophakic eyes on the image quality. The correlation found by the authors between visual field mean defect and both RNFLT and vessel density can also be explained by the influence of nuclear cataract, which causes severity-dependent worsening in all 3 parameters.

Further, no information is given on posterior capsule opacity and the time elapsed since cataract surgery, which both may also considerable influence the between-group comparisons. It is also important to note that retinal nerve fiber layer measurement is fast and less influenced by nuclear cataract than vessel density measurement, which takes a much longer time and therefore is more prone to the effect of cataract-related noise. The authors report that they included only images that had a quality score above the cutoff value recommended by the manufacturer. This is correct, but does not mean that the 2 groups are matched and comparable for the measured values. To remove the influence of image quality differences on the results, either correction should be used, or the authors need to show that the image quality scores do not differ between the matched eyes, or at least between the compared groups.

Second, all RNFLT and vessel density measurements were compared with the unpaired $t$ test between the groups, and no Bonferroni correction was made. For vessel density and RNFLT, the authors investigated 7 and 6 parameters, respectively. This shows that using either the Bonferroni correction or a different $P$-value (eg, $P<0.01$ ) would have been more appropriate. Either of the above obtions was selected by the authors' $P$-values $(0.048$ for global, 0.022 for nasal, and 0.043 for inferonasal vessel density) do not reach the statistically significant level. Thus, the main finding of the study is not supported by the statistics.

The problems described above are rather common in papers and submissions involving exfoliative eyes. The reader may feel that artifacts and effects caused by nuclear cataract (which is strongly associated with exfoliation) are overlooked or remain hidden even in otherwise carefully written studies, wherein all other information pieces are given in detail in the tables. All authors publishing imaging investigations on exfoliative eyes should pay special attention to present all data related to image quality and lens density and their influence on the results; otherwise, the results may not be scientifically convincing.

Gábor Holló, MD, PhD, DSc

Department of Ophthalmology, Semmelweis University, Budapest, Hungary

\section{REFERENCES}

1. Park J-H, Yoo C, Girard MJA, et al Peripapillary vessel density in glaucomatous eyes: comparison between pseudoexfoliation glaucoma and primary open-angle glaucoma. J Glaucoma. [Epub August 21, 2018]. DOI:10.1097/IJG.000000000 0001062 .

2. Hollo G, Naghizadeh F, Hsu S, et al Comparison of the current and a new RTVue OCT software version for detection of ganglion cell complex changes due to cataract surgery. Int Ophthalmol. 2015;35: 861-867.

3. Kim M, Eom Y, Song JS, et al. Effect of cataract grade according to wide-field fundus images on measurement of macular thickness in cataract patients. Korean J Ophthalmol. 2018;32:172-181.

4. Holló G, Katsanos A, Konstas AG. Management of exfoliative glaucoma: challenges and solutions. Clin Ophthalmol. 2015;9:907-919. 